\title{
Statistics suggest BSE now 'Europe-wide'
}

Paris. Europe's veterinary surgeons have urged the European Union (EU) to introduce and enforce measures to ensure that bovine spongiform encephalopathy (BSE) cannot enter the human food chain. Their call comes as new analyses suggest that the incidence of BSE in continental Europe is much higher than officially reported.

EU member states in continental Europe have declared a total of around 50 cases of BSE (see table, right). But some researchers estimate that these countries ought to have declared more than 2,000 cases, given that they imported large quantities of breeding cattle and potentially contaminated meat and bone meal from the United Kingdom (see Nature 381, 544; 1996).

One explanation for this discrepancy, say observers, is that farmers may have been discouraged from reporting cases because many countries slaughter herds where BSE has occurred without adequately compensating farmers.

These estimates of the number of BSE cases in continental Europe are nonetheless an order of magnitude lower than in the United Kingdom, where around 160,000 cases have been reported. It follows that any impact on human health would be correspondingly lower, even if it was established that the agent that causes BSE can pass to humans and cause Creutzfeldt-Jakob disease (CJD). Experts also point out that most of the BSE cases in continental Europe will already have entered the food chain.

Nevertheless, at a meeting in Paris last month, the Federation of Veterinarians of Europe (FEV) acknowledged the BSE crisis is now a "European problem" - and not just a British one - according to one official present. Tougher European measures to protect public health are needed, he argues.

He points out that, until last week, when France banned the human consumption of specified bovine offals (SBO) - the most infective parts, such as brain and spinal cord - (see page 5), the United Kingdom had been the only EU country to have done so. (Switzerland, which is not a member of the EU, had introduced a similar ban.)

\section{Numbers of pure-bred breeding bovines exported by UK to EU member states, 1985 to 1990 Total: 33,424 animals}

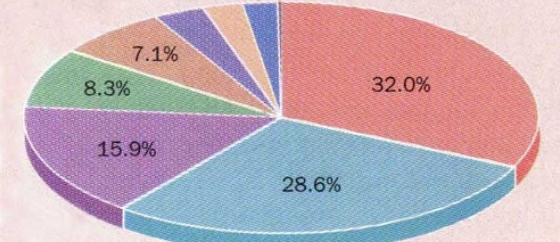

Source: Eurostat and Business and Trade Statistics Ltd
To reassure consumers, "it must be demonstrated beyond any doubt that BSE cannot enter the food chain", says Francis Antony, president of FEV and the British Veterinary Association's spokesman on BSE. In a statement last week, FEV called on the EU to "design, apply and enforce" a comprehensive food hygiene programme "from the stable to the table".

"Consumer perception and the scientific reality of food safety are too far apart," says one FEV official. "The key issue is about keeping brain and spinal cord out of the food chain." Indeed, the FEV statement seems a thinly veiled attack on what one official says is the EU's excessive focus on the culling of UK cattle.

Although culling will precipitate the decline of the epidemic in cattle, it will have little direct impact on human health, argues one FEV official. Eliminating risk to public health requires a ban on the human consumption of SBOs and strict enforcement of deboning and denerving procedures in abattoirs to eliminate infective tissues.

The EU also needs to ensure that adequate resources are made available to enforce any new regulations, says one FEV official. The failure of the United Kingdom to police its early feed and SBO bans has shown that "you can ban things until you are blue in the face", but without proper enforcement this has little impact.

The revised estimates of cases of BSE in mainland EU states come from analyses of UK exports of animal feed and live cattle. Experts predict that imported feed may have resulted in several hundred cases of BSE. But the total is difficult to estimate precisely because the final destination and use of feed are often unknown, while the relationship between tonnage and infectivity is difficult to establish, according to John Wilesmith, of the UK Ministry of Agriculture's Central Veterinary Laboratory in Weybridge.

Better estimates may come from analysis of UK exports of breeding cattle. One group of researchers has estimated, for example, that the United Kingdom exported 57,900 pure-bred breeding bovines between 1985

\section{UK exports of meat and bone meal to EU member states, 1985 to 1990 \\ Total: 71,706 tonnes}

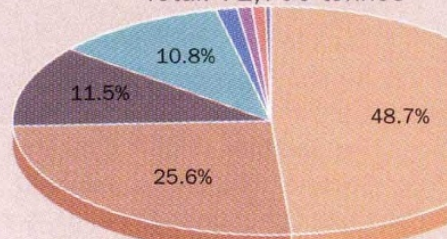

Source: HM Customs and Excise as supplied by Business and Trade Statistics Ltd. France Denmark and 1990, the latter being the year after the EU banned imports of breeding animals older than six months.

One of the scientists, B. E. C. Schreuder from the DLO-Institute for Animal Science and Health in Lelystad, the Netherlands, says that, statistically, around 1,700 of these animals would be expected to have developed BSE.

Such estimates must be taken with caution because of the assumptions they involve, says Schreuder. His estimates of total exports are somewhat higher than records of exports for "pure-bred breeding

\begin{tabular}{|c|c|}
\hline \multicolumn{2}{|c|}{$\begin{array}{l}\text { Number of declared cases of } \\
\text { BSE worldwide (May 1996) }\end{array}$} \\
\hline UK & 158,866 \\
\hline Switzerland & 211 \\
\hline Eire & 125 \\
\hline France & 18 \\
\hline Portugal & 30 * \\
\hline
\end{tabular}

bovines" (see figure, below left) provided by Eurostat - the body that supplies the European Commission with statistics - as he has also included other export categories such as "bulls not intended for slaughter".

Nonetheless, Schreuder is confident that their estimate of BSE cases in continental Europe attributable to cattle exports is of the right order of magnitude. He says it is possible to identify the individual member states most at risk - Portugal, which has declared just 30 cases of BSE, is expected to top this list.

Schreuder says that his warning of underreporting is mainly aimed at countries where lack of regulation might yet allow recycling of BSE and new outbreaks. Wilesmith adds that better data on true BSE levels in continental Europe will be essential to studying the epidemiology of any cases of the new variant of CJD that arise there. The evidence for higher levels of BSE on the European mainland also underlines the need for an effective European CJD surveillance network, he says (see Nature 381, 453; 1996).

Wilesmith asserts that "we were lucky there were not BSE epidemics elsewhere". The factors that led the United Kingdom to be worst affected, he says, probably included the world's highest ratio of sheep to cattle (45 million to 12 million), a high prevalence of scrapie, and the use of high proportions of meat and bone meal in cattle feed.

Other countries may have escaped relatively unscathed only because they had more cattle than sheep, low levels of scrapie, or used less meat and bone meal in cattle feed. Indeed, a new report from the UK Institute of Animal Health suggests that the procedures used in many rendering plants throughout Europe would have been insufficient to inactivate the agent that causes BSE.

Declan Butler 